\title{
ENCOUNTER WITH THE OTHER IN URSULA LE GUIN'S PLANET OF EXILE
}

\author{
All men [are] alien one to another, at times, not only aliens. \\ Planet of Exile, p. 22
}

\begin{abstract}
In this paper we will try to tackle the postcolonial notion of Otherness and its connection to science fiction by analyzing Ursula Le Guin's Planet of Exile. In this novel, a faraway planet is inhabited by two species: the tribe of natives and the tribe of settlers from Earth. We will show how both sides feel about physical and cultural differences between them, and try to conclude what kind of action the author suggests in order to minimize and bridge these dissimilarities. We will also try to show which strategies Ursula Le Guin suggests in order to overcome considerable differences between species/races/ nations which exist not only in her invented universe of the future but also on our planet today.
\end{abstract}

Key words: science fiction, postcolonial studies, the Other

\section{Introduction}

Science fiction of our time is often similar to philosophical tales (Suvin 1965: 557) and this is why it often has an educational function "preaching the good word of human curiosity, fear, and hope" (Suvin 1972: 381). It does not deal with the mere imitation of our world, it should make us question the reality we live in and strive towards changes (Suvin 2009: 129). In its style of writing science fiction ('SF' in further text) can be similar to realism, and the author usually states a number of details from the world he/she describes which helps us experience an SF text as a realistic one. Science fiction authors usually deal with encounters with beings from other planets. Since our (human) race is the only one we know of, the aliens are there to assume the function of the monsters or supernatural beings which have always existed in literature, representing the Other in every sense (Csicsery 2007: 5-6).

\footnotetext{
Faculty of Philology, University of Belgrade, Studentski trg 3, 11000 Belgrade, Serbia; e-mail: mirjana.m.vuckovic@gmail.com
} 
Tamise Van Pelt states that the man saw another man as the Other the first time he noticed the difference in skin color, features, language. The woman was perceived as the Other in comparison to man, and a homosexual as the Other when compared to a heterosexual (Van Pelt 2000: 6, 8). She lists a number of binary oppositions of perceiving oneself and the Other: "white/black, West/East, heterosexual/homosexual, male/female" (Van Pelt 2000: 9). Similar binary opposition can be found in the works of Ursula Le Guin.

One should bear in mind that this perception is always bidirectional, as well as the stereotypes and the division into Us and Them. Tzvetan Todorov says that all of us have the best opinions of ourselves, and, in accordance with that, we only appreciate similarities in others. Even "when we firmly believe that we are objective and nonbiased in our judgements we generally speak only of the differences between us" (Todorov 1994: 60). He also states the opinion of the philosopher Helvetius: "If I were to visit all the peoples in the world, each will have different customs and each will be determined that theirs are the best ones" (Todorov 1994: 27). As if in accordance with this statement, Ursula Le Guin's Other from an unknown planet will reciprocally perceive his visitor as the Other.

Adam Roberts believes that this encounter with difference, with Otherness, is the main contribution of science fiction literature. These differences are usually reduced to stereotypes, and "stereotype is always at the bottom of racism, sexism or any other bigotry" (Roberts 2000: 25-26). An SF work can "attack the stereotype in a more direct, more vivid and more powerful manner" (Roberts 2000: 106). Darko Suvin expresses an opinion that "aliens - utopians, monsters or simply differing strangers are a mirror to man just as the differing country is a mirror for [the author's] world" (Suvin 1972: 374). He emphasizes that this mirror is "not only a reflecting one, it is also a transforming one" (Suvin 1972: 374), thus making the reader question the society he lives in.

\section{Ursula Le Guin's Hainish cycle}

Ursula Le Guin's Hainish cycle consists of several novels and many stories which are not firmly connected. The cycle deals with the development of The League of all Worlds (in some works referred to as the Ekumen), which is not always successful. The League is set in the "unreachable center of the universe" (Nudelman 1975: 4). Lewis Call believes that "[the] Ekumen represents an anarchist alternative to the imperialist 'Galactic empires' so common in late twentieth-century science fiction" (Call 2007: 92). The Ekumen is therefore "intended as the opposite of a colonial power, apparently made so by the wisdom of its elder members, [...] and by the physical constraints of galactic space travel" (Pearson 2007: 190). In Planet of Exile rules for behaviour on the 
planet where an envoy or settlers arrive are listed: "No Religion or Congruence shall be disseminated, no technique or theory shall be taught, no cultural set or pattern shall be exported, nor shall para-verbal speech be used with any non-Communicant highintelligence lifeform, or any Colonial Planet, until it be judged by the Area Council with the consent [...] that such a planet be ready for Control or for Membership" (Le Guin 1966: 42), which means that no influence should be spread on the locals.

Unlike other authors of SF whose works are brimming with technological and scientific inventions, Ursula Le Guin does not include many elements of science. She usually introduces only three factors, one of them being the ability of telepathic communication, "which is more a psychological than a technological factor" (Živković 1987: 13). The hero who arrives to an unknown world usually acquires this ability in time, after making contact and becoming friendly with the inhabitants of the new world, and it actually represents his/her connection with the new co-habitants. The other two factors are more like the classic inventions, and therefore more similar to the usual gadgets and equipment found in the SF literature and films. One of them is ansible, a gadget which makes instantaneous communication with anyone with the same equipment possible. It is somewhat similar to contemporary mobile phones or e-mails. The third invention are the spaceships which can move at speed nearly as fast as light (NAFAL). These ships are used for travelling through space, and, while decades pass on their planets, they do not grow older than several days. They can require help from the League instantaneously through ansible, but years will pass until a ship arrives to the distant planet they are situated on, and they are basically destined to loneliness and isolation. Ursula Le Guin pays more attention to detailing members of various species/races/peoples/sexes/societies and their similarities to and differences from the world we live in today than to inventing numerous technological inventions in order to depict the life in the imaginary world of the future.

\section{Planet of Exile - Encounter with the Other}

Planet of Exile, together with Rocannon's World and City of Illusions, is one of the early novels of this author. Darko Suvin wittily referred to these three novels as her "apprentice trilogy". In all of them "the hero is a stranger superior to the primitive territory" unlike the heroes in her later works (Suvin 1975: 1). These three novels have not been subject of much research especially since she published The Left Hand of Darkness and The Dispossessed. In all three novels she deals with the life on planets populated with a "variety of different peoples inhabiting them and the intrusion of outsiders into these worlds" (Theall 1975: 11). The essence of each of them is the relationship/struggle between good and evil, illusion of the superiority of one of their cultures, as well as well as the role of an individual in the process of significant 
changes occurring in a society. The origin of the topic she dealt with in her later, more popular works, can be found in these works. It is "the total inability of one culture to comprehend another" (Porter 1975: 2), as well as the attempt of the main characters to overcome the differences and establish communication. In order for this to be possible, "it is necessary to recognize differences and to move toward an understanding of these differences" (Theall 1975: 13).

Planet of Exile was published in 1966 and could be described as "[Le Guin's] classic encounter with alienness" (Cummins 1993: 71). The story is set on planet Werel in constellation Gama Draconis III where a group of settlers from Earth landed many years ago. The settlers arrived as a colony which should have helped Werel's inclusion into the League of All Worlds. In the meantime a war occurred and League was attacked by an unknown enemy. Part of the colony returned to Earth in a spaceship, taking with them all means for communication, supposedly the ansible. The other part of the colony stayed on the planet, but we do not know whether they wanted or were forced to do so. Since then they lost every contact or connection with the League and their succeeding generations struggled to survive on this alien and hostile planet.

On planet Werel, native Teverans lead a simple life, without technological inventions, as it was the case on Earth a long time ago. They think of time and space linearly, they know of the present day and the past, and see the future only as far as the next season (Le Guin 1966: 45). Natives refer to the settlers as farborns, alien race, falsemen, and witchfolk due to their ability to communicate without words, using their minds. The settlers refer to them as hilfs (H.I.L.F. - highly intelligent life-form) and think of them as "of stupid stubborn nomads" (Le Guin 1966: 17).

Since none of them perceives the other life form as human, they keep away from each other. They almost never mix, and marriages are not approved of since it is not possible to have offspring: "[A] farborn takes only one wife, so a true-woman marrying him would bear no sons. [...] Because human and farborn can't concieve together! [...] Either a sterile mating or else miscarriages, misformed monsters that don't come to term" (Le Guin 1966: 9). In her book Colonialism/Postcolonialism Ania Loomba says: "Different species were supposed to be unable to sexually reproduce with each other. Thus the interpretation of 'race' as 'species' cries to deny the possibility of inter-mixing between races" (Loomba 1998: 116). It was believed in the past that this was the nature's way to prevent inter-racial mixing and, with it, the dilution of the preferred, white blood (Young 1995: 8). This is the exact attitude that Ursula Le Guin has presented in this novel.

The settlers who have been there for generations are slowly dying out, although local diseases do not affect them. Each year fewer children are born and the main character, Agat, believes that the world they live on is slowly killing them "rejecting 
the graft" (Le Guin 1966: 19). When his people arrived at this planet, they respected the rule that they could not use the inventions unknown to that world, in accordance with the League's cultural embargo. Therefore many skills have been forgotten as time passed, they teach their children only old trades, and find it more and more difficult to understand the old books of their ancestors. Since they have changed to such significant extent, Agat wonders: "If ever a ship, as in the old hopes and tales, soared down in fire from the stars, would the men who stepped from it know them to be men?" (Le Guin 1966: 19-20).

The plot begins when a girl named Rolery, who belongs to the tribe of natives, gets lost and meets Jakob Agat Altera, one of the settlers' leaders. The two of them start communicating through their minds in spite of all their differences and in time fall in love. Agat explains to her that people can pass on the mind communication skill. In a conversation with Rolery's father, Agat tries to persuade him to unite their two peoples in order to be able to resist a common enemy, the tribe of Gaals which always emigrates south destroying anything they find on their way, before the winter which will last for several years comes. Agat and Rolery get married in spite of the resistance from their kin.

At the beginning of the story, Rolery says she had imagined farborns as "hunched back and spiderlike" (Le Guin 1966: 3), she notices that they look one straight into the eye, unlike her people, and that some of them do not have much darker skin "than men" (Le Guin 1966: 3). She still feels fear, but makes sure that "[n]one of these grinning black falsemen would dare think she was afraid" (Le Guin 1966: 4). When she meets Agat, his face seems to her "strong, rough and dark, with grim, bright eyes, with the dark eyes of the alien" (Le Guin 1966: 6). When they shake hands "she seemed to hold against her palm a handful of darkness, where his touch had been" (Le Guin 1966: 7). She later notices that he moves and sits differently from her people and concludes that they are "very slightly, but completely, unfamiliar" (Le Guin 1966: 26).

In this novel, Ursula Le Guin begins to pay a lot of attention to the description of eyes and the way someone looks at someone else, as a characteristic which is essential when distinguishing between different species/races. Rolery believes that looking someone straight in the eye is strange, and wonders: "Why did they stare in one's face so, like corpses or fish? Warm-blooded animals and human beings did not go staring in one another's eyes that way" (Le Guin 1966: 7). Agat notices that Rolery always looks at him "aside, away, glancing, golden, alien" (Le Guin 1966: 18). Agat's and Rolery's father Wold's eyes are compared directly: "Wold's eyes were dull yellow like the winter sun, and no white showed under the slanting lids. Agat's eyes were dark, iris and pupul dark, white-cornered in the dark face: strange eyes to meet the gaze of, unearthly" (Le Guin 1966: 50). 
Rolery's father Wold thinks that farborns "always [had] that arrogance, that air of thinking themselves as good as men, whether they really believed it" or not (Le Guin 1966: 11). Agat greets him as an equal (Le Guin 1966: 11) which Wold does not appreciate. The visitor tries to explain that his people have fewer children each year, their numbers are decreasing and they are therefore no danger to the natives. They both need alliance against the Gaals if they intend to survive. None of this reaches Wold, and he answers: "My people are men, and you are farborn. Keep your black talk for your own black fate!" (Le Guin 1966: 13), he does not recognize the fact that they are both in danger and that they can survive only if they overcome their differences. Although he once had a wife who was a member of Agat's people, he does not approve of his daughter marrying "among the false-men, to bear no sons" (Le Guin 1966: 51).

The idea of many farborns being killed does not seem to Teverans as a tragic one. The chief of one clan says: "What if this city perishes in the Southing? No men live in it! Let them perish [...] They're not men, there's no good in them! [...] They want our women so they can bring up human children as theirs!" (Le Guin 1966: 21-22). In a similar way, members of Agat's people say: "Man and unman can't work together. [...] Never hold your hand out to any creature that belongs to this world" (Le Guin 1966: 35). We can see that both parties are prejudiced against the other one. Desperate because the negotiations are not successful, Agat thinks about Rolery's people: "Ignorant, bigoted, quarrelsome, mealy-faced, yellow-eyed barbarians, woodheaded hilfs, let'em all burn!" (Le Guin 1966: 15). They are “[a] herd of stupid stubborn nomads - they'll never learn" (Le Guin 1966: 17). Here we can see what David Porter refers to as "the total inability of one culture to comprehend another" (Porter 1975: 2). Only Wold, who once had a wife who was a member of Agat's people, after a while develops an understanding for what the leader of the settlers told him. He believes that Agat is not a fraud, and does not let prejudices prevail, concluding that "[a]11 men [are] alien one to another, at times, not only aliens" (Le Guin 1966: 22).

When he falls in love with Rolery, Agat's views of natives slowly begin to change. They are no longer "mealy-faces", but "silvery-looking men" (Le Guin 1966: 31-32), and he refers to them as 'men' for the first time. At that moment members of Rolery's tribe attack him, but her cousin Umaksuman rescues him. The two men share food, and Agat concludes: "Friend, enemy what the hell" (Le Guin 1966: 46). Rolery's father Wold later says to Agat: "You are a chief, a lord. I am not. But I am a man, and you are not. What likeness between us?" (Le Guin 1966: 51), to which Agat answers: "At least no grudge, no hate" (Le Guin 1966: 51). The change begins with this slow disappearance of hatred.

When Rolery spends time with him she "feared him, but nothing else. Nothing, no one" (Le Guin 1966: 42), showing feelings of ambivalence (Ashcroft et al. 1998: 
12-13) since she feels both attraction and fear towards him. She feels that his people hate her because of their marriage, because "she [is] human and they [are] not" (Le Guin 1966: 43). The two of them in time become closer, she begins to communicate with him in her mind and concludes that this huge difference between them is the very thing that has brought them closer together and freed them: "She the stranger, the foreigner, of alien blood and mind [...] shared nothing at all with him, but had met him and joined with him wholly and immediately across the gulf of their great difference: as if it were that difference, the alienness between them, that let them meet, and that in joining them together, freed them" (Le Guin 1966: 49).

Rolery notices that Agat is the only one who refers to both peoples as 'humans' (Le Guin 1966: 66), he is the only one who sees them as belonging to the same species. She realizes how small and insignificant the differences between them are while helping doctor Wattock after the enemy attack. The doctor explains to her that these are "[t]otally superficial variations, color and eye-structure and all that [...] [T] he difference is on a lower level, and is very small - one molecule in the hereditary chain. [...] Life tends to adapt, after all" (Le Guin 1966: 69). During the attack, it turns out that the farborns are beginning to adjust to the new world and are getting ill from the diseases they used to be resistant to, for example a bacterial infection which Tevarans call 'weapon-evil' (Le Guin 1966: 63). This perhaps indicates that breeding between the two species could be possible in the future. The author implies that changes are always possible, and that the processes of adjustment and evolution are unstoppable. For some, this is not good news since they cannot accept mixing with the locals. One of the wounded men who listens to their conversation curses the possibility of mixing the races and fertility, because he believes that their, human blood, would thus be diluted (Le Guin 1966: 70). This view is similar to Robert Young's writing, that in the past it was believed that mixing between races would lead to degeneration and deterioration of an ideal, pure race (Young 1995: 95). When the battle is over, Agat searches "for the alien, the stranger, his wife" (Le Guin 1966: 73), with whom he established a complete closeness.

\section{Conclusion}

We noticed that the author's idea of Otherness is very complex but also multilayered and bidirectional. Stereotypes and negative views of differences can be observed both in the hosts/locals and the guests/settlers. Both peoples at the beginning of the story see someone who is different as a freak, a monster, an animal - as unhuman. The author points out that a change in attitude is possible, but that it can only be achieved by means of communication between the opposed sides. One is able to change his attitude towards the Other only when one gets to know him/her. Getting 
to know the Other is the means to alter the way one thinks and behaves towards the Other, to accept him/her as a person who may be different in physical appearance, but is not considerably different otherwise.

We can conclude that in this novel various attitudes on differences between members of two species/races can be found. First of all, considerable attention is paid to the description of different appearance, features, the shape of eyes, the way one looks at someone, or their skin color. These differences are the cause of hatred which exists between the settlers and the natives. Differences exist on various levels, such as education and the ability to communicate through mind. At the beginning, both sides see the other people as unhuman, as lower species, as animals, but in time this attitude changes.

The love between the two main characters contributes to the appearance of understanding, and Ursula Le Guin explains that these differences existing between Rolery and Agat are the very things which connected them and bridged the mentioned differences, first between these two people and then between their species/races which, at the end of the novel, we begin to see as two peoples. This particular personal relationship which is described in this novel further influences the relationships between species/races/peoples since "it is at heart of human communication..." (Theall 1975: 7). Ursula Le Guin is telling us that the way to achieve understanding is always through getting to know the Other, through communicating with them.

Communication is one of the essential topics in Ursula Le Guin's work, and the author will continue to develop this topic in her later works.

\section{References}

Ashcroft, B. et al. (1998). Key Concepts in Post-Colonial Studies. London and New York: Routledge.

Call, L. (2007). Postmodern Anarchism in the Novels of Ursula K. Le Guin. Substance: The Future of Anarchism, 36(2), Issue 113, 87-105.

Csicsery-Ronay, I. Jr. (2007). Some Things We Know about Aliens. The Yearbook of English Studies: Science fiction, 37(2), 1-23.

Le Guin, U. (1966). Planet of Exile. New York: Ace Books.

Loomba, A. (1998). Colonialism/ Postcolonialism. London: Routledge.

Nudelman, R. (1975). An Approach to the Structure of Le Guin's SF. Science Fiction Studies, 2(3). (20 August 2017) <http://www.depauw.edu/sfs/backissues/7/ nudelman7art.htm>. 
Pearson, W. G. (2007). Postcolonialism/s, Gender/s, Sexuality/ies and the Legacy of The Left Hand of Darkness: Gwyneth Jones's Aleutians Talk Back. The Yearbook of English Studies, 37(2), Science Fiction, 182-196.

Porter, D. L. (1975). The Politics of Le Guin's Opus. Science Fiction Studies, 2(3). (20 August 2017) <http://www.depauw.edu/sfs/backissues/7/porter7art.htm>. Roberts, A. (2000). Science Fiction. London and New York: Routledge.

Suvin, D. (1965). Od Lukijana do Lunjika - povijesni pregled i antologija naučnofantastičke literature. Zagreb: Epoha.

Suvin, D. (1972). On the Poetics of the Science Fiction Genre. College English, 34(3), Dec., 372-382.

Suvin, D. (1975). Parables of De-Alienation: Le Guin's Widdershins Dance.

Science Fiction Studies, 2(3). (20 August 2017) <http://www.depauw.edu/sfs/ backissues/7/suvin7art.htm>.

Suvin, D. (2009). Naučna fantastika, spoznaja, sloboda. Beograd: SlovoSlavia.

Theall, D. F. (1975). The Art of Social-Science Fiction: The Ambiguous Utopian Dialectics of Ursula K. Le Guin. Science Fiction Studies, 2(3). (20 August 2017) $<$ http://www.depauw.edu/sfs/backissues/7/theall7art.htm>.

Todorov, C. (1994). Mi i drugi, trans. by Branko Jelić, Mira Perić and Mirjana Zdravković. Beograd: Biblioteka XX vek.

Van Pelt, T. (2000). Otherness. (17 August 2015) <pmc.iath.virginia.edu/text-only/ issue. 100/10.2vanpelt.txt>.

Young, R. J. C. (1995). Colonial Desire, Hibridity in Theory, Culture and Race. London and New York: Routledge.

Živković, Z. (1987). Desna ruka svetlosti Ursule Legvin. Foreword in U. Legvin: Rokanonov svet. Beograd: Narodna knjiga/Partizanska knjiga, 7-38. 